University of Nebraska - Lincoln

DigitalCommons@University of Nebraska - Lincoln

Cell bank characterization and fermentation optimization for production of recombinant heavy chain C-terminal fragment of botulinum neurotoxin serotype $\mathrm{E}\left(\mathrm{rBoNTE}\left(\mathrm{H}_{\mathrm{C}}\right)\right.$ : Antigen $\left.\mathrm{E}\right)$ by

\title{
Pichia pastoris
}

\author{
Jayanta Sinha \\ University of Nebraska-Lincoln \\ Mehmet Inan \\ University of Nebraska-Lincoln \\ Sarah Fanders \\ University of Nebraska-Lincoln \\ Shinichi Taoka \\ University of Nebraska-Lincoln, staoka1@unl.edu \\ Mark Gouthro \\ University of Nebraska-Lincoln \\ Follow this and additional works at: https://digitalcommons.unl.edu/chemengbiochemeng

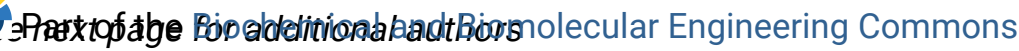

Sinha, Jayanta; Inan, Mehmet; Fanders, Sarah; Taoka, Shinichi; Gouthro, Mark; Swanson, Todd; Barent, Rick; Barthuli, Ardis; Loveless, Bonnie M.; Smith, Leonard A.; Smith, Theresa; Henderson, Ian; Ross, John; and Meagher, Michael M., "Cell bank characterization and fermentation optimization for production of recombinant heavy chain $\mathrm{C}$-terminal fragment of botulinum neurotoxin serotype $\mathrm{E}\left(\mathrm{rBoNTE}\left(\mathrm{H}_{\mathrm{C}}\right)\right.$ : Antigen E) by Pichia pastoris" (2007). Papers in Biochemical Engineering. 12.

https://digitalcommons.unl.edu/chemengbiochemeng/12

This Article is brought to you for free and open access by the Chemical and Biomolecular Engineering Research and Publications at DigitalCommons@University of Nebraska - Lincoln. It has been accepted for inclusion in Papers in Biochemical Engineering by an authorized administrator of DigitalCommons@University of Nebraska - Lincoln. 


\section{Authors}

Jayanta Sinha, Mehmet Inan, Sarah Fanders, Shinichi Taoka, Mark Gouthro, Todd Swanson, Rick Barent, Ardis Barthuli, Bonnie M. Loveless, Leonard A. Smith, Theresa Smith, Ian Henderson, John Ross, and Michael M. Meagher 


\title{
Cell bank characterization and fermentation optimization for production of recombinant heavy chain $\mathrm{C}$-terminal fragment of botulinum neurotoxin serotype $\mathrm{E}\left(\mathrm{rBoNTE}\left(\mathrm{H}_{\mathrm{c}}\right)\right.$ : Antigen $\left.\mathrm{E}\right)$ by Pichia pastoris
}

\author{
Jayanta Sinha $^{\text {a }}$, Mehmet Inan ${ }^{a}$, Sarah Fanders ${ }^{\text {a }}$, Shinichi Taoka ${ }^{a}$, Mark Gouthro ${ }^{\text {a }}$, \\ Todd Swanson ${ }^{\mathrm{a}}$, Rick Barent ${ }^{\mathrm{a}}$, Ardis Barthuli ${ }^{\mathrm{a}}$, Bonnie M. Loveless ${ }^{\mathrm{b}}$, \\ Leonard A. Smith ${ }^{\mathrm{b}}$, Theresa Smith ${ }^{\mathrm{b}}$, Ian Henderson ${ }^{\mathrm{c}}$, \\ John Ross ${ }^{\mathrm{c}}$, Michael M. Meagher ${ }^{\mathrm{a}, *}$ \\ a Biological Process Development Facility, Department of Chemical and Biomolecular Engineering, \\ University of Nebraska-Lincoln, Lincoln, NE 68588-0466, United States \\ ${ }^{\mathrm{b}}$ United States Army Medical Research Institute of Infectious Diseases, Toxicology Division, Fort Detrick, \\ Fredrick, MD 21702-5011, United States \\ ${ }^{\mathrm{c}}$ DynPort Vaccine Company LLC, A CSC Company, 64 Thomas Johnson Drive, Frederick, \\ MD 21702, United States
}

Received 30 November 2005; received in revised form 12 July 2006; accepted 20 July 2006

\begin{abstract}
A process was developed for production of a candidate vaccine antigen, recombinant C-terminal heavy chain fragment of the botulinum neurotoxin serotype E, $\mathrm{rBoNTE}\left(\mathrm{H}_{\mathrm{c}}\right)$ in Pichia pastoris. P. pastoris strain $\mathrm{GS} 115$ was transformed with the $\mathrm{rBoNTE}\left(\mathrm{H}_{\mathrm{c}}\right)$ gene inserted into pHILD4 Escherichia coli-P. pastoris shuttle plasmid. The clone was characterized for genetic stability, copy number, and $\operatorname{BoNTE}\left(\mathrm{H}_{\mathrm{c}}\right)$ sequence. Expression of $\operatorname{rBoNTE}\left(\mathrm{H}_{\mathrm{c}}\right)$ from the Mut ${ }^{+}$HIS4 clone was confirmed in the shake-flask, prior to developing a fed-batch fermentation process at 5 and $19 \mathrm{~L}$ scale. The fermentation process consists of a glycerol growth phase in batch and fed-batch mode using a defined medium followed by a glycerol/methanol transition phase for adaptation to growth on methanol and a methanol induction phase resulting in the production of $\mathrm{rBoNTE}\left(\mathrm{H}_{\mathrm{c}}\right)$. Specific growth rate, ratio of growth to induction phase, and time of induction were critical for optimal $\mathrm{rBoNTE}\left(\mathrm{H}_{\mathrm{c}}\right)$ production and minimal proteolytic degradation. A computer-controlled exponential growth model was used for process automation and off-gas analysis was used
\end{abstract}

\footnotetext{
* Corresponding author.

E-mail address: mmeagherl@unl.edu (M.M. Meagher).
} 
for process monitoring. The optimized process had an induction time of $9 \mathrm{~h}$ on methanol and produced up to $3 \mathrm{mg}$ of $\mathrm{rBoNTE}\left(\mathrm{H}_{\mathrm{c}}\right)$ per gram wet cell mass as determined by HPLC and Western blot analysis.

(C) 2006 Elsevier B.V. All rights reserved. This article is a U.S. government work, and is not subject to copyright in the United States.

Keywords: Recombinant C-terminal heavy chain fragment of the botulinum neurotoxin serotype E; Pichia pastoris; Cell-bank characterization; Fed-batch fermentation; Potency studies

\begin{tabular}{|c|c|}
\hline \multicolumn{2}{|c|}{ Nomenclature } \\
\hline$D$ & derivative factor \\
\hline$F$ & methanol feed rate $(\mathrm{g} / \mathrm{h})$ \\
\hline I & integral constant \\
\hline$m$ & maintenance coefficient $(\mathrm{g} / \mathrm{g} / \mathrm{h})$ \\
\hline$P$ & proportional constant \\
\hline$K$ & cell density correction factor \\
\hline$T$ & induction time \\
\hline$V$ & fermentation medium volume (1) \\
\hline$X$ & wet cell density $(\mathrm{g} / \mathrm{l})$ \\
\hline & $\begin{array}{l}\text { observed yield of biomass to substrate } \\
(\mathrm{g} / \mathrm{g})\end{array}$ \\
\hline \multicolumn{2}{|c|}{ Greek letters } \\
\hline$\varepsilon$ & error \\
\hline$\mu$ & specific growth rate $\left(\mathrm{h}^{-1}\right)$ \\
\hline$v$ & specific methanol utilization rate $(\mathrm{g} / \mathrm{g} / \mathrm{h})$ \\
\hline \multicolumn{2}{|c|}{ Subscripts } \\
\hline $\max$ & maximum \\
\hline $\mathrm{MeOH}$ & methanol \\
\hline$t$ & at that particular time \\
\hline 0 & at initial time \\
\hline
\end{tabular}

\section{Introduction}

Botulinum neurotoxins, the most poisonous substances known to mankind, are finding increased attention due to their potential threat as a biological warfare agent (Medical and Public Health Management, 2001). The toxin produced by the bacteria, Clostridium botulinum and other closely related clostridial species, is a zinc endoprotease that acts to prevent the release of acetylcholine thus blocking neuromuscular transmission which, if untreated, progressively leads to skeletal muscle paralysis and eventually death from respiratory failure (Dreyer and Habermann, 1986; Simpson, 1986; Pellizzari et al., 1999). There are seven antigenically distinct serotypes of the neurotoxin designated as A, B, $\mathrm{C}_{1}, \mathrm{D}, \mathrm{E}, \mathrm{F}$ and $\mathrm{G}$ (Hatheway, 1989). These neurotoxins cleave specific sites on the soluble $N$-ethylmaleimidesensitive factor-attachment protein receptor proteins or SNARE proteins (Schiavo et al., 1993; Foran et al., 1996; Niemann et al., 1994; Blasi et al., 1993). SNARE proteins are key components of the nerve cell system responsible for the release of the neurotransmitter acetylcholine into the synapse at the neuromuscular junction, which ultimately stimulates the associated muscle (Jahn and Südhof, 1999). The SNARE proteins consist of synaptobrevin on the vesicle membrane and syntaxin and synaptosome-associated protein of $25 \mathrm{kDa}$ (SNAP25) at the synaptic membrane. Serotype E cleaves SNAP25 which prevents assembly of the synaptic fusion complex and therefore the fusion of the acetylcholine-containing vesicle and the synaptic membrane. This prevents the release of acetylcholine into the synapse resulting in a lack of stimulation of the downstream muscle fibers and results in muscle paralysis (Schiavo et al., 1993; Simpson, 1986; Byrne and Smith, 2000). Structurally, the botulinum neurotoxins have two domains, a $100 \mathrm{kDa}$ heavy chain and a $50 \mathrm{kDa}$ light chain bound together by a disulfide bond (DasGupta, 1989; DasGupta and Sugiyama, 1972). Functionally, the heavy chain consists of two subdomains, a domain at the $\mathrm{N}$-terminus responsible for membrane transfer into the nerve cell, and a domain at the $\mathrm{C}$-terminus responsible for binding to the nerve cell membrane. The light chain is zinc dependent proteases which cleave the SNARE proteins (Smith, 1998). However, both the non-toxic heavy and light chain fragments are antigenic and can elicit protective immunity in animals challenged with the toxin (Byrne and Smith, 2000). To counteract the threat from the lethal botulinum neurotoxin, various attempts were made to develop an effective vaccine against all serotypes. Initial attempts included development of a pentavalent (A-E) toxoid vaccine by the U.S. Army for immunizing Army personnel who might be exposed to biological 
warfare. However, the toxoid vaccines poses several risks which include handling functional toxins, large volumes of formaldehyde and the current requirements for specific manufacturing facilities for growing sporeforming bacteria (Byrne and Smith, 2000). In addition, the toxoid vaccine candidates, which contain crude extract of inactivated Clostridial proteins, might influence immunogenicity of the vaccine (Byrne and Smith, 2000). Recombinant vaccines can be custom designed to be safe and effective. Proper choice of the vector can make the vaccine easy to produce and the culture easy to maintain, and thereby reduce production costs. Unwanted portions of the antigen that do not elicit protective immunity or pose health risks can be eliminated from the vaccine and is a huge advantage over the toxoids (Smith, 1998; Clare et al., 1991). The recombinant botulinum vaccine candidates were first expressed in Escherichia coli. However, large quantities of soluble antigen E could not be produced in this expression host due to formation of inclusion bodies which made refolding difficult resulting in a low yield (Smith et al., 2004).

Subsequently, a Pichia pastoris expression system was evaluated for expression of $\operatorname{rBoNTE}\left(\mathrm{H}_{\mathrm{c}}\right)$. Previously, P. pastoris was used to express high levels (27\% of the total cell protein or about $12 \mathrm{~g} / \mathrm{L}$ of culture) of tetanus toxin fragment $\mathrm{C}$, a subunit vaccine candidate designed to provide protection against tetanus neurotoxin (Clare et al., 1991). P. pastoris is a commercially useful organism for high level expression of recombinant proteins with many advantages (Zhang et al., 2000; Gellissen, 2000). The organism grows on defined media to high cell densities on either glycerol or methanol as the sole carbon source (Zhang et al., 2000; Sinha et al., 2003) and heterologous protein production is under the control of a strong but tightly regulated alcohol oxidase promoter induced by methanol. P. pastoris can be grown to the desired cell density on glycerol as the carbon source and then on methanol for high level heterologous protein production (Cregg et al., 1987). In addition, expression can be controlled to direct expression of target proteins to either the intracellular compartment or to the extracellular medium by secretion. Expression studies with $\mathrm{rBoNTB}\left(\mathrm{H}_{\mathrm{c}}\right)$ found that secretion of $\mathrm{rBoNTB}\left(\mathrm{H}_{\mathrm{c}}\right)$ resulted in glycosylation due to $\mathrm{N}$-glycosylation recognition sequences even though native botulinum neurotoxin is not glycosylated. Glycosylated $\mathrm{rBoNTB}\left(\mathrm{H}_{\mathrm{c}}\right)$ did not provide protection in a mouse efficacy model while the unglycosylated $\mathrm{rBoNTB}\left(\mathrm{H}_{\mathrm{c}}\right)$ control provided the necessary protection (Byrne et al., 1998; Smith, 1998). The decision was made to express all $\mathrm{rBoNT}\left(\mathrm{H}_{\mathrm{c}}\right)$ intracellularly to eliminate potential glycosylation. The expression of $\operatorname{rBoNTE}\left(\mathrm{H}_{\mathrm{c}}\right)$ is under the control of the alcohol oxidase promoter in a methanol utilization positive strain $\left(\mathrm{Mut}^{+}\right)$, which is induced by methanol as the sole carbon source and repressed by other carbon sources like glycerol or glucose (Inan and Meagher, 2001).

The purpose of this work is to characterize a research cell bank suitable for Current Good Manufacturing Practice (CGMP) and to develop a fermentation process suitable for transfer to a CGMP facility for production of $\mathrm{rBNTE}\left(\mathrm{H}_{\mathrm{c}}\right)$ for use as a vaccine candidate in clinical testing.

\section{Materials and methods}

\subsection{Strain development}

A $\operatorname{rBoNTE}\left(\mathrm{H}_{\mathrm{c}}\right)$ gene was synthesized based on the sequence of $C$. botulinum NCTC 11219 strain and $P$. pastoris codon usage (Loveless, 2001). The codon optimized $\mathrm{rBoNTE}\left(\mathrm{H}_{\mathrm{c}}\right)$ gene was inserted into the pHILD4 expression vector (Sreekrishna and Kropp, 1996) at the EcoRI site (Fig. 1). After amplification in E. coli DH5 $\alpha$, the plasmid was linearized with SstI and then transformed into P. pastoris GS115 (his4) by spheroplast procedure as described by Cregg and Kimberly (1998). Cells growing on minimal dextrose (MD) media lacking histidine were screened for copy number on YPD plates containing increased concentrations of antibiotic, geneticin (G418) up to $10 \mathrm{mg} / \mathrm{mL}$. Cells grown in $25 \mathrm{~mL}$ of minimal glycerol medium without histidine ( $1.34 \%$ yeast nitrogen base (YNB), $4 \times 10^{-5} \%$ biotin, $1 \%$ glycerol/L sterile distilled water) to an $\mathrm{OD}_{600 \mathrm{~nm}}$ of 4-8 were transferred to $2 \mathrm{~L}$ baffled flasks containing $175 \mathrm{~mL}$ of minimal methanol medium (1.34\% YNB, $4 \times 10^{-5} \%$ biotin, $0.5 \%$ methanol) (Loveless, 2001). The cultures were harvested at $22.5 \mathrm{~h}$ by centrifugation at $2000 \times g$ for $5 \mathrm{~min}$ at $4{ }^{\circ} \mathrm{C}$. The cells were ruptured and the cell extract after centrifugation at $10,000 \times g$ was examined for best production by Western blot analysis. The best producing clone, P. pastoris $\left[\mathrm{rBoNTE}\left(\mathrm{H}_{\mathrm{c}}\right) \mathrm{E} 3\right]$ was selected as the production clone. 


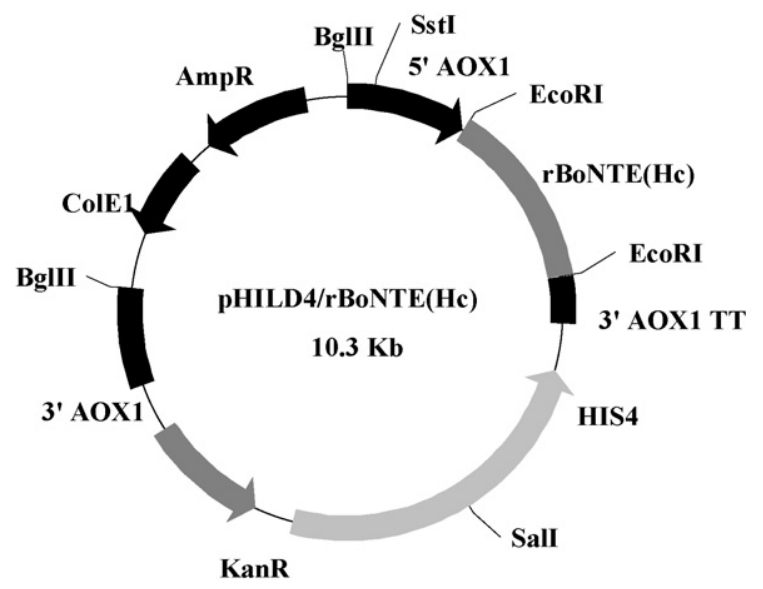

Fig. 1. The expression vector pPHILD4/rBoNTE $\left(\mathrm{H}_{\mathrm{c}}\right)$ The restriction enzyme site EcoRI is utilized for the insertion of the gene of the $\operatorname{rBoNTE}\left(\mathrm{H}_{\mathrm{c}}\right)$. The pHILD4 plasmid was derived by insertion of the gene encoding aminoglycoside $3^{\prime}$-phosphotransferase from pUC-4K into pHIL-D1 (Sreekrishna and Kropp, 1996).

\subsection{Cell bank production}

A single colony from a YPD plate was transferred to a test tube containing $10 \mathrm{~mL}$ of YPD medium. The test tube was incubated at $30^{\circ} \mathrm{C}$ and $200 \mathrm{rpm}$ in a rotary shaker for $24 \mathrm{~h}$. Five millilitres of culture was used as inoculum for $100 \mathrm{~mL}$ of YPD media in $500 \mathrm{~mL}$ baffled shake flask. The culture was grown up to $8-10 \mathrm{OD}_{600 \mathrm{~nm}}$ using the same conditions described above. When the desired optical density was obtained, glycerol was added to a final concentration of $15 \%$ $(\mathrm{v} / \mathrm{v})$. The culture and glycerol were mixed thoroughly, and $1 \mathrm{~mL}$ of mixture was distributed aseptically into $2 \mathrm{~mL}$ cryovials (Sarstedt, Hayward, CA). The vials were stored in the vapor phase of liquid nitrogen.

\subsection{Cell bank characterization experiments}

\subsubsection{Culture identity test}

The culture identity test was performed by Accugenix Inc. (Newark, DE). In brief, a 500 bp region of the D2 segment of the 25-28S rRNA locus was amplified from purified DNA using the PE Biosystems' MicroSeq DS LSU rDNA fungal sequencing kit. Both DNA strands of the amplified fragment were sequenced using di-deoxy terminator sequenc- ing chemistry and analyzed using ABI Prism 377 DNA sequencers. The data was assembled, aligned, and compared to a database of 1200 validated entries using the PE Biosystems' MicroSeq Microbial Analysis software.

\subsubsection{Cellular morphology and cell viability}

Cellular morphology was determined by the gram staining process. The cells were visualized with a microscope under oil immersion at $100 \times$ magnification to distinguish cell size and shape. Cell viability was obtained by counting colonies of cells grown on agar plates after suitable dilution of the original culture and reported as colony forming unit (cfu/mL).

\subsubsection{Structural integrity of the inserted rBoNTE $\left(H_{c}\right)$ gene}

Structural integrity of $\operatorname{rBoNTE}\left(\mathrm{H}_{\mathrm{c}}\right)$ gene after cell bank manufacturing with $P$. pastoris $\mathrm{rBoNTE}\left(\mathrm{H}_{\mathrm{c}}\right)$ E3 clone was assessed by Southern blot analysis. Genomic DNA was isolated from $P$. pastoris $\mathrm{rBoNTE}\left(\mathrm{H}_{\mathrm{c}}\right)$ clone using MasterPure Yeast DNA Purification Kit (Epicentre, Madison, WI) from YPD grown culture. One microgram of genomic DNA was digested with BstXI, EcoRI, EcoRV, HindIII, NheI and XbaI and separated on a $0.8 \%$ Agarose gel. The DNA was transferred to a positively charged nylon membrane, Zeta-Probe GT (BioRad, Hercules, CA) using the method described by Southern (1975) and fixed to the membrane by a UV-Crosslinker. The membrane was pre-hybridized for $30 \mathrm{~min}$ at $40^{\circ} \mathrm{C}$ with a hybridization solution supplied by DIG High Prime DNA Labeling and Detection Starter Kit II (Roche Diagnostics Corporation, Indianapolis, IN). Upon completion of pre-hybridization, the DIG labeled whole $\operatorname{rBoNTE}\left(\mathrm{H}_{\mathrm{c}}\right)$ gene in the same hybridization buffer was applied to the membrane as a probe. This hybridization step was performed for $16 \mathrm{~h}$ at $40^{\circ} \mathrm{C}$. Washing and detection protocol was carried out according to the manufacturer's instructions.

\subsubsection{Insert copy number}

Insert copy number was also estimated using Southern blot analysis. The chromosomal DNA of P. pastoris $\mathrm{rBoNTE}\left(\mathrm{H}_{\mathrm{c}}\right)$ E3 clone, GS115, and pHILD4/rBoNTE $\left(\mathrm{H}_{\mathrm{c}}\right)$ plasmid DNA were digested

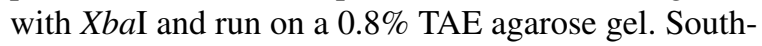


ern blotting was performed according to the previously described method using the $1600 \mathrm{bp} \mathrm{NcoI/XbaI} \mathrm{frag-}$ ment of HIS4 gene encoded on the plasmid.

\subsubsection{Insert DNA sequencing}

The DNA sequence of the $\operatorname{rBoNTE}\left(\mathrm{H}_{\mathrm{c}}\right)$ gene inserted into the $P$. pastoris genome was determined as follows. The cells were induced for $12 \mathrm{~h}$ in methanol containing media (BMMY) before extracting total RNA. The cells were disrupted in a bead beater with TRI Reagent ${ }^{\circledR}$ (Molecular Research Center Inc., Cincinnati, $\mathrm{OH}$ ) and $0.5 \mathrm{~mm}$ silica zirconia beads with 7 cycles of $1 \mathrm{~min}$ each, equilibrated at room temperature for $5 \mathrm{~min}$ and then vortexed with chloroform. After incubation at room temperature for $10 \mathrm{~min}$ the resulting suspension was centrifuged and the aqueous phase was transferred to new microfuge tubes and extracted with isopropanol. These samples were centrifuged and the pellets of RNA were washed with 75\% ethanol, centrifuged and air-dried. The pellets were re-suspended in FORMAZOL ${ }^{\circledR}$, (Molecular Research Center Inc., Cincinnati, OH) incubated for $10 \mathrm{~min}$ at $60^{\circ} \mathrm{C}$ in a multi-block heater and the RNA was stored at $-80^{\circ} \mathrm{C}$. Messenger RNA was purified from total RNA with Qiagen Oligotex mRNA Spin Column Purification Kit (Qiagen, Valencia, CA). The mRNA was used as template for one step RT-PCR using SuperScript One-Step RT-PCR for Long Templates kit from Invitrogen (Carlsbad, CA) using forward 5' GAATTCACCATGGGAGAGAG- $3^{\prime}$ and reverse $5^{\prime}$ GAATTCCTATTATTTTTCTTGCCATCC-3' primers.

The PCR product was ligated into pCRII-TOPO vector using TOPO TA Cloning Kit Dual Promoter from Invitrogen (Carlsbad, CA). Two positive clones were sequenced with a total of eight primers to ensure the sequence was covered twice.

\subsection{Inoculum preparation}

Frozen culture was thawed and added to previously sterilized BMGY medium (1\% yeast extract, $2 \%$ $(\mathrm{w} / \mathrm{v})$ soytone, $0.1 \mathrm{M}$ potassium phosphate buffer-pH $6.0,1.3 \%(\mathrm{w} / \mathrm{v})$ yeast nitrogen base and $1.2 \%(\mathrm{w} / \mathrm{v})$ glycerol) in shake flasks. The culture was grown for approximately $24 \mathrm{~h}$ to an $\mathrm{OD}_{600 \mathrm{~nm}}$ of $4-5$. The seed culture $(100 \mathrm{~mL})$ was transferred aseptically to $2 \mathrm{~L}$ of the fermentation medium in $5 \mathrm{~L}$ Bioflo III/3000 fermentors or $500 \mathrm{~mL}$ seed culture was transferred aseptically to $10 \mathrm{~L}$ of the fermentation medium in $22 \mathrm{~L} \mathrm{NLF} 22$ fermentors.

\subsection{Fermentation control}

Bioflo III/3000 fermentors (5 L) were interfaced with NBS BioCommand32 (New Brunswick Scientific (NBS) Company, Edison, NJ) software while NLF22 fermentors (22 L) (Bioengineering AG) were interfaced with Batch Expert (Intelligent Laboratory Solutions, Inc., Naperville, IL) for complete supervisory control. The closed-loop feed control system consisted of a feed pump for methanol, balance for methanol, and a controller interface (Zhang et al., 2000). The NBS controller converted the feed rate to a pump setting which was then sent to the pump through the BioCommand32 hardware. The NLF Bioengineering fermentors were controlled by Mitsubishi FX programmable logic controllers (PLCs) which were interfaced with Batch Expert via an open connectivity (OPC) server and an OPC bridge. A dynamic data exchange (DDE) bridge was used to interface the Batch-Expert software with a VG Prima $\delta B$ mass spectrometer (Thermo Electron Corporation, Houston, TX), which was used for online analysis of residual methanol and other byproducts, as well as determining the respiratory quotient. Open database connectivity (ODBC) bridge was also set up to exchange data between Batch-Expert and the database. The amount of methanol delivered was measured using a balance as the difference between the initial mass in the methanol tank and the current mass (Sinha et al., 2003). Both Biocommand 32 and Batch Expert were set up to calculate the feed rates during glycerol and methanol feeding based upon the elapsed induction time and the amount of methanol actually delivered.

\subsection{Fermentation conditions}

P. pastoris cells were grown on basal salts medium which contained in $\mathrm{g} / \mathrm{L}$ deionized water: $\mathrm{KH}_{2} \mathrm{PO}_{4}, 42.9 ;\left(\mathrm{NH}_{4}\right)_{2} \mathrm{SO}_{4}, 5.0 ; \mathrm{CaSO}_{4} \cdot 2 \mathrm{H}_{2} \mathrm{O}, 0.5$; $\mathrm{MgSO}_{4} \cdot 7 \mathrm{H}_{2} \mathrm{O}, 11.7 ; \mathrm{K}_{2} \mathrm{SO}_{4}, 14.3$; glycerol, 20. In addition, $4.35 \mathrm{~mL} / \mathrm{L}$ PTM1 salt was filter sterilized and added to the medium. PTM1 salts contained (in $\mathrm{g} / \mathrm{L}$ deionized water): $\mathrm{CuSO}_{4} \cdot 5 \mathrm{H}_{2} \mathrm{O}, 2.0 ; \mathrm{ZnCl}_{2}, 7.0 ; \mathrm{NaI}$, $0.08 ; \mathrm{FeSO}_{4} \cdot 7 \mathrm{H}_{2} \mathrm{O}, 22.0 ; \mathrm{MnSO}_{4} \cdot \mathrm{H}_{2} \mathrm{O}, 3.0$; Biotin, $0.2 ; \mathrm{Na}_{2} \mathrm{MoO}_{4} \cdot 2 \mathrm{H}_{2} \mathrm{O}, 0.2$; boric acid, $0.02 ; \mathrm{CoCl}_{2}, 0.5$ 
along with $\mathrm{H}_{2} \mathrm{SO}_{4}, 2 \mathrm{~mL}$. All chemicals were tested for composition and upon release by the Biological Process Development Facility, University of NebraskaLincoln (UNL-BPDF) Quality Assurance Unit were issued for use. All media components were entered in the media preparation logbook and copies were included in the UNL-BPDF's standard fermentation batch record, which are used for all research fermentations. Technology transfer batch records were used when the fermentation was scaled up to the $19 \mathrm{~L}$. The batch record provides details of all phases of the fermentation with necessary checks, compliance with accepted ranges, and space to document any process deviations. Critical information also included culture information and seed bank lot number, manufacturer and lot number of all chemicals and supplies, and a detailed equipment list. The batch record referenced all pertinent standard operating procedures (SOP), which were also transferred to the contract manufacturing outsourcing (CMO) along with Material Safety Data Sheets (MSDS) and other safety precautions.

After inoculation of the fermentation medium, the cells were grown on glycerol (glycerol batch phase) until the glycerol was consumed, which was marked by a sudden and sharp increase in the dissolved oxygen level (a DO spike). This was followed by a glycerol fed-batch phase (linear feed: $13.3 \mathrm{~g} / \mathrm{L} / \mathrm{h}$ ) to obtain a targeted cell density. A $63 \%$ (w/v) glycerol $(13.3 \mathrm{~g} / \mathrm{L} / \mathrm{h})$ feed containing $12 \mathrm{~mL} / \mathrm{L}$ PTM1 salts was used as the carbon source during the glycerol fed-batch phase. At the end of the glycerol fed-batch phase, $2 \mathrm{~g} \mathrm{MeOH} / \mathrm{L}$ of broth was injected into the fermentor as a bolus to induce product gene expression. Simultaneously, the glycerol feed rate was programmed to decrease linearly from $13.3 \mathrm{~g} / \mathrm{h} / \mathrm{L}$ to zero over a 3 -h period. This 3 -h period is considered the transition phase as the cells adapt to methanol as the sole carbon source (Zhang et al., 2000). A pre-calibrated methanol sensor was used to monitor the level of methanol from off-gas which started decreasing after $1 \mathrm{~h}$ of the methanol addition and reached undetectable levels between 1.5 and $2 \mathrm{~h}$ after the addition of the bolus of methanol to the fermentor. At this time a continuous feed of methanol containing $12 \mathrm{~mL} / \mathrm{L}$ of PTM1 salts (methanol fed-batch phase) was started and the cells were grown using an exponential methanol feed. Fermentations were performed at $30^{\circ} \mathrm{C}$ and $\mathrm{pH}$ was controlled at 5.0 using saturated aqueous ammonium hydroxide throughout the fermen- tation. The dissolved oxygen (DO) was set at $40 \%$ of saturation and was controlled by a DO cascade of agitation (maximum of $800 \mathrm{rpm}$ for $5 \mathrm{~L}$ fermentor and $1000 \mathrm{rpm}$ for $22 \mathrm{~L}$ fermentor) followed by supplementing with pure oxygen to air sparging at $1 \mathrm{vvm}$. Samples were taken at regular intervals and analyzed for $\operatorname{rBoNTE}\left(\mathrm{H}_{\mathrm{c}}\right)$ by Western blot (qualitative) and HPLC (quantitative). A defined sampling schedule and sampling instructions were given in the batch record. The cells were harvested at the end of fermentation whenever necessary to support downstream processing and purification experiments.

\subsection{Detection of $r B o N T E\left(H_{c}\right)$ by Western blot}

Fermentation samples were collected at various intervals and centrifuged at $8000 \times g$ for $10 \mathrm{~min}$ at $4{ }^{\circ} \mathrm{C}$. The pellet was washed by re-suspending the pellet in cold lysis buffer ( $50 \mathrm{mM}$ sodium phosphate, $\mathrm{pH} 7.5$ ), centrifuged at $10,000 \mathrm{rcf}$ for $5 \mathrm{~min}$ at $4{ }^{\circ} \mathrm{C}$, decanting the supernatant, and re-suspending the pellet in the cold lysis buffer $(10 \mathrm{~mL}$ buffer/g pellet) with $50 \mu \mathrm{L} /(\mathrm{g}$ cell pellet) each of $0.5 \mathrm{M}$ EDTA and $0.2 \mathrm{M}$ phenylmethylsulfonylfluoride (PMSF). The cells were broken in a bead beater at $5{ }^{\circ} \mathrm{C}(3.7-3.9 \mathrm{~g}$ cold zirconia beads/g cell pellet) with 3 cycles of 1 min burst each with $5 \mathrm{~min}$ rest between cycles at $5{ }^{\circ} \mathrm{C}$. The broken cells were centrifuged at $5000 \times g$ for $5 \mathrm{~min}$ at $5^{\circ} \mathrm{C}$ to separate the cell extract from the cell debris and the zirconia beads and then re-centrifuged at $18,000 \times g$ for $10 \mathrm{~min}$ at $5^{\circ} \mathrm{C}$ to remove any particulates prior to analysis. Protein bands from fermentation samples were separated on a $10 \%$ Bis-Tris gel with MOPS, pH 7.7 as the running buffer and then transferred to a (polyvinylidine difluoride) PVDF membrane using a semi-dry transfer apparatus (Bio-Rad, Hercules, CA). The PVDF membrane was soaked with blotto $(5 \%$ (w/v) skimmed milk powder in Tris buffer saline) and treated sequentially with anti-BoNTE $\left(\mathrm{H}_{\mathrm{c}}\right)$ antibodies derived from chickens for $1 \mathrm{~h}$ at a dilution of 1:3000, washed at least twice with Tris buffered saline (TBS) followed by treatment with peroxide labeled affinity purified goat anti-chicken secondary antibodies (Kirkland and Perry, Gaithersburg, MA) at a dilution of 1:6667 for $1 \mathrm{~h}$. The membrane was again washed several times with TBS and the image was developed using the ECL + plus Western Blotting Detection System (Amersham Biosciences, NJ). Purified $\operatorname{rBoNTE}\left(\mathrm{H}_{\mathrm{c}}\right)$ was used as the standard. 


\subsection{Estimation of $r B o N T E\left(H_{c}\right)$ by HPLC}

The concentration of $\operatorname{rBoNTE}\left(\mathrm{H}_{\mathrm{c}}\right)$ in the cell extract was estimated using a Waters (Milford, MA) high performance liquid chromatography system comprising a Model 600 four-solvent pump, Model 486 UV-vis detector and a Model 717 Plus auto-sampler. Waters HPLC software, Empower 5.0, was used for instrument control, data collection and data processing. Analysis was performed using a methyl acrylate copolymer (TSK gel phenyl 5-PW) hydrophobic interaction column $(10 \mu \mathrm{m}, 7.5 \mathrm{~mm} \times 75 \mathrm{~mm}$; Tosoh BioScience, Tokyo, Japan). The cell extract ( $0.5 \mathrm{mg}$ protein per injection) was injected on to the column which was pre-conditioned with a mixture of $25 \%(\mathrm{v} / \mathrm{v})$ of mobile phase A (0.2 M Tris-HCl, 2 mM EDTA, pH 7.7), $40 \%$ (v/v) of mobile phase B (1 M ammonium sulfate, $2 \mathrm{mM}$ EDTA) and 35\% (v/v) mobile phase C (2 mM EDTA) for $1 \mathrm{~h}$. The $\mathrm{rBoNTE}\left(\mathrm{H}_{\mathrm{c}}\right)$ protein was eluted using a programmed gradient of the mobile phases $\mathrm{A}-\mathrm{C}$ for $55 \mathrm{~min}$ at $1 \mathrm{~mL} / \mathrm{min}$. The composition of the individual solutions is the same as described earlier.

\subsection{Protease assay}

Protease activity in the cell extract was analyzed by measuring the fluorescent intensity of the liberated dye-labeled peptides from highly quenched fluorescent casein (Bodipy-casein FL) as a substrate (Jones et al., 1997). One unit of protease activity was defined as the unit increase in fluorescence intensity of Bodipycasein FL as substrate with excitation at $485 \mathrm{~nm}$ and a fluorescence emission at $530 \mathrm{~nm}$. Samples were analyzed using a SpectraMax M2 fluorescence spectrometer (Molecular Devices Corporation, Sunnyvale, CA) equipped with a 96 well micro plate reader.

\subsection{Mouse potency bioassay}

The potency of the purified $\mathrm{rBoNTE}\left(\mathrm{H}_{\mathrm{c}}\right)$ was determined using a mouse potency bioassay. A total of 7 groups of 10 mice each (Control: CD-1 mice, females, Charles River, Raleigh, NC) were intramuscularly vaccinated with $0.1 \mathrm{~mL}$ of diluted antigen. The antigen was diluted three-fold beginning at $8.1 \mu \mathrm{g}$ to $11 \mathrm{ng}$ in $25 \mathrm{mM}$ sodium succinate, $15 \mathrm{mM}$ sodium phosphate, $\mathrm{pH} 5.0$ with 5\% mannitol and $0.2 \%$ Alhydrogel (HCI Biosector, Frederikssund, Denmark) as adjuvant. Twenty-one days following vaccination the mice were challenged with 1000 mouse intraperitoneal $\mathrm{LD}_{50}$ of botulinum type $\mathrm{E}$ toxin complex. Numbers of survivors were recorded 5 days post-challenge. Results were evaluated by the analysis of survival rates and calculation of the effective dose by probit analysis. Probit dose-response models were fitted to dose lethality data and the estimated parameters of the probit dose-response model were used to calculate $\mathrm{ED}_{50}$ values, i.e., the theoretical effective dose of vaccine at which $50 \%$ of the animals vaccinated survive challenge. The $95 \%$ confidence interval for the $\mathrm{ED}_{50}$ was calculated concurrently.

\section{Results and discussion}

\subsection{Strain development and selection}

The expression vector pPHILD4/rBoNTE $\left(\mathrm{H}_{\mathrm{c}}\right)$ was constructed as shown in Fig. 1 (Loveless, 2001). The restriction enzyme site EcoRI was utilized for the insertion of the $\operatorname{rBoNTE}\left(\mathrm{H}_{\mathrm{c}}\right)$ gene fragment. The plasmid was linearized at the AOX1 promoter site with restriction enzyme, SstI before transforming P. pastoris GS115 strain. Transformants were selected by expression of the histidinol dehydrogenase gene demonstrated by growth on histidine deficient regeneration medium (Cregg and Kimberly, 1998). Dose dependent resistance to the antibiotic geneticin (G418) was conferred by accumulation of the resistance determining enzyme aminoglycoside phosphostransferase (APT). $\mathrm{His}^{+}$colonies which survived at $10 \mathrm{mg} / \mathrm{mL}$ G418 were screened for expression of $\operatorname{rBoNTE}\left(\mathrm{H}_{\mathrm{c}}\right)$ by methanol induction in shake flask culture. The best expressing clone was chosen for further studies by comparing on the basis of degree of band intensity (results not shown).

\subsection{Cell bank characterization}

Viable cell count of seed bank was $6.56 \times 10^{8}$ (cfu/mL) based on colony forming units (cfu) on Luria-Bertany (LB) plates by plating serial dilutions after freeze/thaw cycle of seed bank. Gram staining of the cells revealed that the cells were gram positive, ovoid cells with or without budding (results not shown) confirming the expected P. pastoris cell morphology. Cell growth on histidine-lacking media (MGY plates) also confirmed that GS115 host strain $\mathrm{His}^{-}$pheno- 
type was recovered by transforming with pHILD4 $\mathrm{rBoNTE}\left(\mathrm{H}_{\mathrm{c}}\right)$.

The $\operatorname{rBoNTE}\left(\mathrm{H}_{\mathrm{c}}\right)$ gene sequence was confirmed by sequencing of the RT-PCR product, which was the expected $1.3 \mathrm{~kb}$ fragment as described in Section 2. The consensus sequences of aligned DNA sequences with eight primers matched the theoretical $\operatorname{rBoNTE}\left(\mathrm{H}_{\mathrm{c}}\right)$ DNA sequence as well as the deduced amino acid sequence of $\operatorname{rBoNTE}\left(\mathrm{H}_{\mathrm{c}}\right)$ protein.

The copy number of the $\operatorname{rBoNTE}\left(\mathrm{H}_{\mathrm{c}}\right)$ gene inserted into the chromosome of $P$. pastoris $\mathrm{rBoNTE}\left(\mathrm{H}_{\mathrm{c}}\right) 3 \mathrm{E}$ clones was estimated by Southern blot analysis (Fig. 2). The GS1 15 host strain resulted in a single band from the defective histidinol dehydrogenase (his4) gene when the genomic DNA was cut with $X b a I$ enzyme and probed with a $N c o \mathrm{I} / \mathrm{XbaI}$ fragment of the HIS4 gene (Fig. 2, lane 3). The transformed host resulted in two bands, the $3 \mathrm{~kb}$ band corresponding to the chromosomal copy of his 4 gene, and an additional $10 \mathrm{~kb}$ band corresponding to a copy of HIS4 gene from the expression vector (Fig. 2, lane 2). Copy number was estimated as a ratio of the intensity of the $10 \mathrm{~kb}$ band to the his 4 band (lane $2,71 / 22=3.22$ ). The experiment was repeated twice and the average copy number value obtained was 3.2. The copy number cannot be a fractional number, therefore, the copy number of $\operatorname{rBoNTE}\left(\mathrm{H}_{\mathrm{c}}\right)$ gene in $P$. pastoris $\left(\mathrm{rBoNTE}\left(\mathrm{H}_{\mathrm{c}}\right) \mathrm{E} 3\right)$ was estimated as three.

Structural integrity of $\mathrm{rBoNTE}\left(\mathrm{H}_{\mathrm{c}}\right)$ in $P$. pastoris $\operatorname{rBoNTE}\left(\mathrm{H}_{\mathrm{c}}\right)$ E3 clone was assessed by Southern blot analysis. This time the genomic DNA of the P. pas-

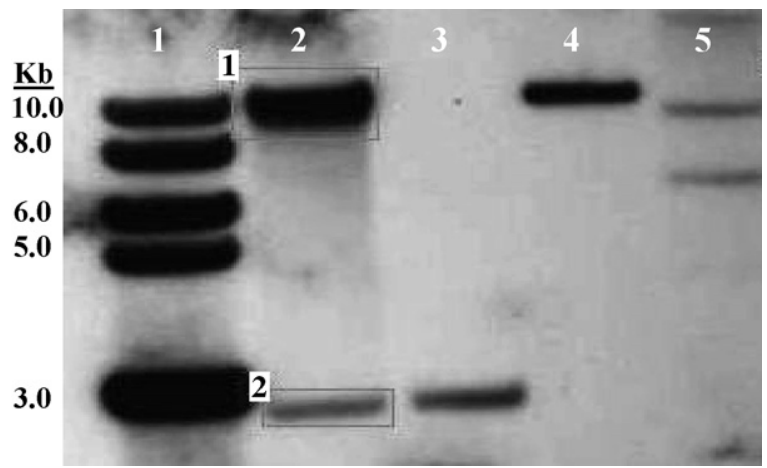

Fig. 2. Southern blot of GS115 host and Pichia pastoris $\mathrm{rBoNTE}\left(\mathrm{H}_{\mathrm{c}}\right) \mathrm{E} 3$ strain using HIS4 as a probe. Chromosomal DNAs were cut with $\mathrm{XbaI}$ enzyme. Lane 1, DNA ladder; lane 2, P. pastoris $\mathrm{rBoNTE}\left(\mathrm{H}_{\mathrm{c}}\right) \mathrm{E} 3$ strain; lane 3, GS115 host strain; lane 4, pHILD4/rBoNTE $\left(\mathrm{H}_{\mathrm{c}}\right)$; lane 5, DIG ladder.

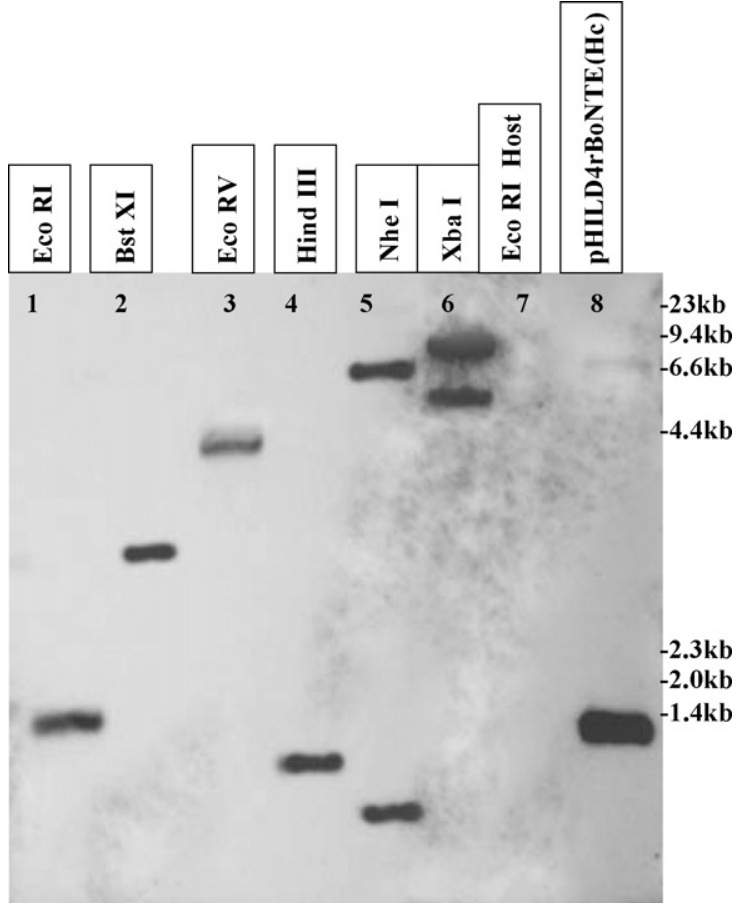

Fig. 3. Southern blot of GS115 host and P. pastoris $\mathrm{rBoNTE}\left(\mathrm{H}_{\mathrm{c}}\right) \mathrm{E} 3$ strain using $\mathrm{rBoNTE}\left(\mathrm{H}_{\mathrm{c}}\right)$ as a probe. Lanes 1-6 are genomic DNA of $P$. pastoris $\mathrm{rBoNTE}\left(\mathrm{H}_{\mathrm{c}}\right) \mathrm{E} 3$ cut with enzyme that are indicated as above the lanes; lane 7, genomic DNA of host starin GS115 cut with EcoRI; lane 8, pHILD4/rBoNTE $\left(\mathrm{H}_{\mathrm{c}}\right)$ plasmid DNA cut with EcoRI.

toris $\mathrm{rBoNTE}\left(\mathrm{H}_{\mathrm{c}}\right) \mathrm{E} 3$ clone was digested by different enzymes and hybridized with DIG labeled whole $\operatorname{rBoNTE}\left(\mathrm{H}_{\mathrm{c}}\right)$ gene. The EcoRI digestion resulted in the expected $1.37 \mathrm{~kb}$ single band for transformed strain and no corresponding bands for the host strain (Fig. 3, lane 1). This band aligned as expected with $1.37 \mathrm{~kb}$ band of plasmid pHILD4rBoNTE $\left(\mathrm{H}_{\mathrm{c}}\right)$ digested with EcoRI restriction enzyme. Two bands were observed when genomic DNA was cut with NheI enzyme since the $\mathrm{rBoNTE}\left(\mathrm{H}_{\mathrm{c}}\right)$ gene contain an internal NheI site. BstXI digestion resulted in an expected $3 \mathrm{~kb}$ band (Fig. 3, lane 2) since $B s t \mathrm{XI}$ digestion of the pHILD4/rBoNTE $\left(\mathrm{H}_{\mathrm{c}}\right)$ drops a $3 \mathrm{~kb}$ band from the plasmid by cutting outside of the $\operatorname{rBoNTE}\left(\mathrm{H}_{\mathrm{c}}\right)$ gene.

\subsection{Shake flask growth kinetics and effect of inoculum age on fermentation}

The P. pastoris $\mathrm{rBoNTE}\left(\mathrm{H}_{\mathrm{c}}\right) \mathrm{E} 3$ clone was grown for $72 \mathrm{~h}$ under identical conditions in triplicate as described 
in Section 2. The lag phase lasted $12 \mathrm{~h}$, after which the cells grew exponentially at $\mu_{\text {observed }}=0.1701$. The effect of inoculum age on fermentation productivity was evaluated. Inocula from shake flasks at the beginning of the exponential phase, middle of the exponential phase and the end of stationary phase, 22.75, 29.75 and $46.75 \mathrm{~h}$, respectively, were used to inoculate three 5-L fermentors. Differences in the $\mathrm{OD}_{600}$ 's of the samples was compensated for by varying the volume used to inoculate the fermentor $\left(\mathrm{OD}_{600}^{*}\right.$ volume $\left.=3286\right)$ so that the fermentor's initial $\mathrm{OD}_{600}$ 's were the same. The length of the batch phase with an inoculum age of $22.75 \mathrm{~h}$ was $19 \mathrm{~h}$. The length of the batch phase increased to $22.25 \mathrm{~h}$ for both the 29.75 and $46.75 \mathrm{~h}$ inoculums. The age of the inoculum did not affect the final cell density of the batch phase indicating the yield coefficient of the cells was the same regardless of the age of the inoculum. Optimizing the inoculum age reduced total fermentation time by approximately $3 \mathrm{~h}$.

\subsection{Maximum methanol specific growth rate in 5-Lfermentor}

The maximum specific growth rate on methanol, $\mu_{\mathrm{MeOH}, \max }$ was determined by maintaining the residual methanol concentration in the fermentor below $2 \mathrm{~g} / \mathrm{L}$ using a methanol sensor, which is below the inhibitory level (Zhang et al., 2000), A serial PID equation was developed to maintain the methanol set point below $2 \mathrm{~g} / \mathrm{L}$ in the fermentor as described below:

$F=P \varepsilon+I \int \varepsilon \mathrm{d} t+D \times \varepsilon \mathrm{d} t$

where $F$ is the pump output in percent of maximum; $\varepsilon$ the error between sensor and set point; $P$ the proportional factor; $I$ the integral factor and $D$ is the derivative factor.

Values of $P=2, I=0.01$ and $D=30$ was found to be optimal for smooth control of methanol addition.

The $\mu_{\mathrm{MeOH} \text {,max }}$ averaged $0.0567 \mathrm{~h}^{-1}$ in duplicate experiments, which is lower than $0.0709 \mathrm{~h}^{-1}$ for $\operatorname{rBoNTA}\left(\mathrm{H}_{\mathrm{c}}\right)$ (Zhang et al., 2000) and $0.08 \mathrm{~h}^{-1}$ for the wild type strain X-33 (GS115, $\mathrm{His}^{+}$) (unpublished results), indicating that there is a metabolic strain induced by production of $\operatorname{rBoNTE}\left(\mathrm{H}_{\mathrm{c}}\right)$. Recombinant $\operatorname{BoNTE}\left(\mathrm{H}_{\mathrm{c}}\right)$ analysis by HPLC revealed that cell growth at $\mu_{\mathrm{MeOH}, \max }$, resulted in a low yield of $\operatorname{rBoNTE}\left(\mathrm{H}_{\mathrm{c}}\right)\left(0.51 \mathrm{mg} \mathrm{rBoNTE}\left(\mathrm{H}_{\mathrm{c}}\right) / \mathrm{g} \mathrm{WCW}\right)$ and the

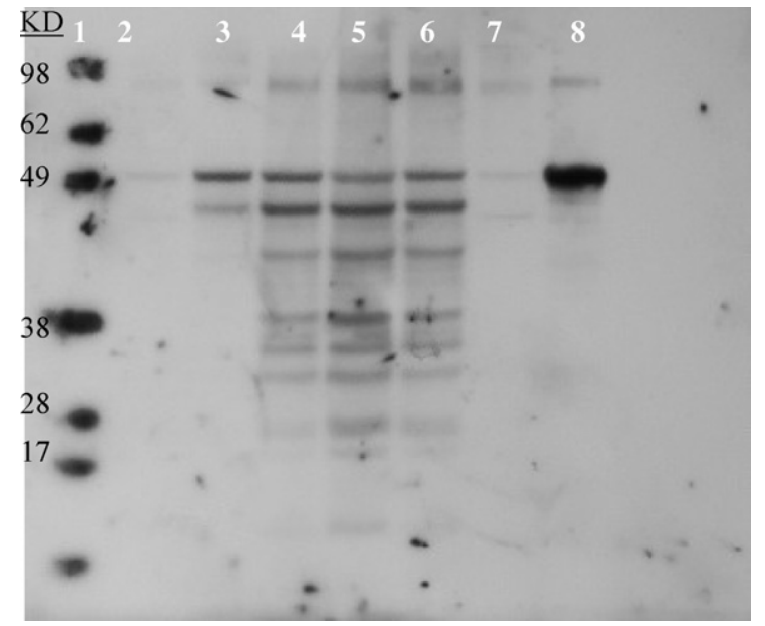

Fig. 4. Western blot of time profile of $\operatorname{rBoNTE}\left(\mathrm{H}_{\mathrm{c}}\right)$ production growing at $\mu_{\max }$; lane $1, \mathrm{M}$ - marker; lane $2,0 \mathrm{~h}$; lane 3, $1.9 \mathrm{~h}$; lane 4 , $22.4 \mathrm{~h}$; lane 5, $29 \mathrm{~h}$; lane 6, $34 \mathrm{~h}$, lane $7,45 \mathrm{~h}$; lane $8, \operatorname{rBoNTE}\left(\mathrm{H}_{\mathrm{c}}\right)$ standard. All times refer to elapsed induction time.

Western blot showed that $\mathrm{rBoNTE}\left(\mathrm{H}_{\mathrm{c}}\right)$ was substantially degraded at $22.4 \mathrm{~h}$ of methanol induction (Fig. 4). It has previously been observed that faster growth on methanol elicits higher protease accumulation in $P$. pastoris (Sinha et al., 2003, 2005) increasing the likelihood of proteolytic degradation of the product. Hence, growth rates below the maximum specific growth rates were investigated to determine an optimal growth rate for $\operatorname{rBoNTE}\left(\mathrm{H}_{\mathrm{c}}\right)$.

\subsection{Optimal specific growth rate on methanol}

Cells were grown on methanol at specific growth rates of $0.02,0.03,0.04$ and $0.05 \mathrm{~h}^{-1}$ and the effect on $\operatorname{rBoNTE}\left(\mathrm{H}_{\mathrm{c}}\right)$ production was observed. The specific growth rates were controlled using a model feed equation described by Zhang et al. (2000):

$F=(0.84 \mu+0.0071) K\left(X_{0} V_{0}\right) \mathrm{e}^{\mu t}$

where $F$ is the methanol feed rate $(\mathrm{g} / \mathrm{h}) ; X_{0}$ the wet cell density at the beginning of methanol feed $(\mathrm{g} / \mathrm{l}) ; t$ the time of methanol fed-batch phase; $V$ the fermentation medium volume (l) at the beginning of methanol feed and $\mu$ is the specific cell growth rate $\left(\mathrm{h}^{-1}\right)$.

Initially, a cell density correction factor of $K=0.86$ was introduced to account for shrinkage and changes in wet cell density due to transition of carbon source from 
glycerol to methanol, which lasted approximately the first $2-3 \mathrm{~h}$ of methanol feeding. Since this only lasts for $2-3 \mathrm{~h}$, a value of $K=1$ was used. The observed growth rates closely matched the growth rates used in the growth model. Maximum $\mathrm{rBoNTE}\left(\mathrm{H}_{\mathrm{c}}\right)(1.93 \mathrm{mg} / \mathrm{g}$ WCW) was obtained when the cells were grown between $\mu=0.02$ and $0.03 \mathrm{~h}^{-1}$. Subsequent experiments showed that optimum $\operatorname{rBoNTE}\left(\mathrm{H}_{\mathrm{c}}\right)$ production occurred at a specific growth rate of $0.0267 \mathrm{~h}^{-1}$, which is the optimum for $\operatorname{rBoNTA}\left(\mathrm{H}_{\mathrm{c}}\right)$ (Zhang et al., 2000). Time course analysis of $\operatorname{rBoNTE}\left(\mathrm{H}_{\mathrm{c}}\right)$ samples by HPLC and Western blots showed that, irrespective of the specific growth rate on methanol, the maximum $\mathrm{rBoNTE}\left(\mathrm{H}_{\mathrm{c}}\right)$ was produced between $8 \pm 3$ and $22 \pm 3 \mathrm{~h}$ of induction approximately. After reaching maximum value at $22 \pm 3 \mathrm{~h}$ of induction approximately, $\operatorname{rBoNTE}\left(\mathrm{H}_{\mathrm{c}}\right)$ production decoupled from cell growth and $\mathrm{rBoNTE}\left(\mathrm{H}_{\mathrm{c}}\right)$ decreased steadily to undetectable levels after around $45 \mathrm{~h}$ of induction. The maximum yield of intact $\operatorname{rBoNTE}\left(\mathrm{H}_{\mathrm{c}}\right)$ was obtained at $9 \mathrm{~h}$ of induction.

Total amount of intracellular proteases were analyzed at different times during the methanol induction. It was observed that protease activity increased from the start of methanol induction and reached a maximum value at $9 \mathrm{~h}$ (following $\operatorname{BoNTE}\left(\mathrm{H}_{\mathrm{c}}\right)$ production) and remained at a constant level throughout the rest of the methanol induction phase (Fig. 5). The protease activity was found to have a direct correlation with anti-

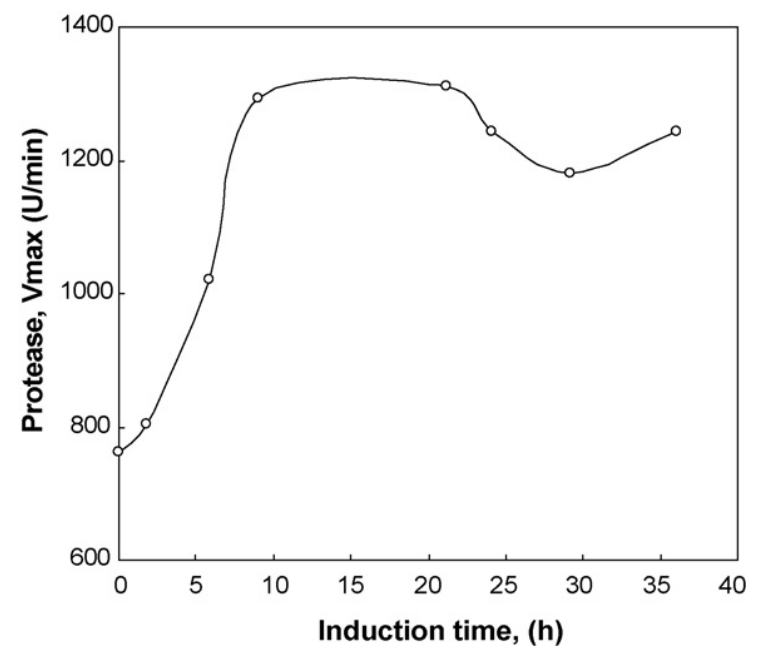

Fig. 5. Protease activities in cell extracts of time course samples from fermentation in $5 \mathrm{~L}$ bioreactor. gen E production. It was determined that $\operatorname{rBoNTE}\left(\mathrm{H}_{\mathrm{c}}\right)$ purified from a $9 \mathrm{~h}$ induction was stable at $4-8{ }^{\circ} \mathrm{C}$ for 7 days as compared to $\mathrm{rBoNTE}\left(\mathrm{H}_{\mathrm{c}}\right)$ purified from a $27 \mathrm{~h}$ induction which degraded 5-10\% based on SDS-PAGE under the same conditions (data not shown). It was this experiment that decided the $9 \mathrm{~h}$ methanol induction.

\subsection{Extended glycerol feed rate and optimum $\mathrm{MeOH}$ induction time}

The effect of growing $P$. pastoris cells to various high cell densities on glycerol prior to methanol induction was investigated. The objective was to determine the effect of extended glycerol feeding on protein expression and the optimal induction wet cell density for maximum product yield. The wet cell densities at the beginning of induction were varied from 200, 250, 300 and $350 \mathrm{~g} / \mathrm{L}$ by growing the cells on a constant glycerol feed rate for an extended period of time. The cells were fed glycerol, as the sole carbon source, until they reached their desired wet cell weight (WCW) prior to a $9 \mathrm{~h}$ methanol induction. It was observed that the maximum specific yield of $\operatorname{rBoNTE}\left(\mathrm{H}_{\mathrm{c}}\right)$ per gram of wet cells was attained when cells were induced at a WCW of $200 \mathrm{~g} / \mathrm{L}$ (Fig. 6). In comparison, induction at a WCW of $100 \mathrm{~g} / \mathrm{L}$ resulted in the same $\operatorname{BoTNE}\left(\mathrm{H}_{\mathrm{c}}\right)$ specific yield as a WCW of $200 \mathrm{~g} / \mathrm{L}$. Induction at higher WCW resulted in a lower productivity per unit cell mass.

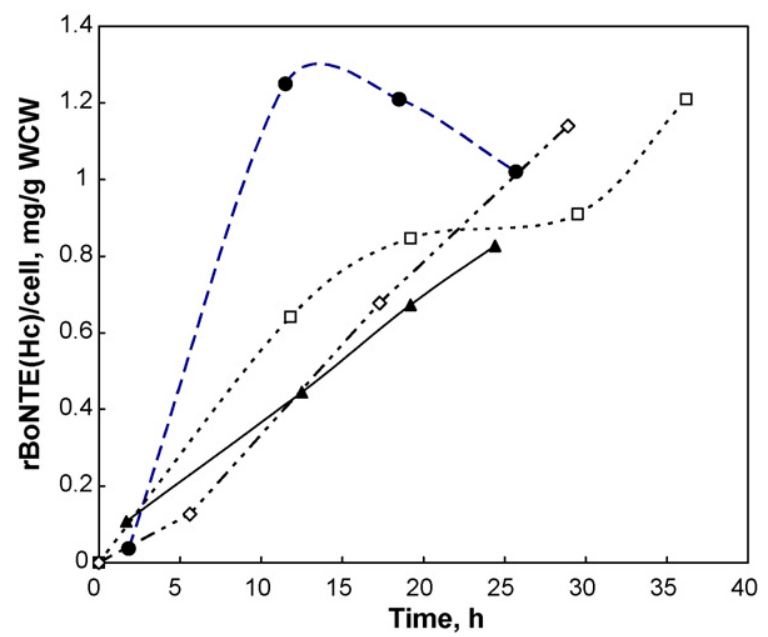

Fig. 6. Time course of $\operatorname{rBoNTE}\left(\mathrm{H}_{\mathrm{c}}\right)$ production after induction at different initial wet cell densities. (○) $200 \mathrm{~g} / \mathrm{L}$; ( $\square$ ) $250 \mathrm{~g} / \mathrm{L}$; (ム) $300 \mathrm{~g} / \mathrm{L} ;(\diamond) 350 \mathrm{~g} / \mathrm{L}$. 


\subsection{Scale-up of fermentation}

The $\mathrm{rBoNTE}\left(\mathrm{H}_{\mathrm{c}}\right)$ fermentation process was scaledup to a $22 \mathrm{~L}$ Bioengineering NLF22 fermentor (Wald, Switzerland) to confirm product yield prior to transfer for CGMP production at the $100 \mathrm{~L}$ scale. A technology transfer batch record was implemented for the $22 \mathrm{~L}$ fermentation in preparation for transfer to a CGMP facility. In the batch record, the entire fermentation process was divided into several phases like inoculum batch up, inoculation, incubation, fermentor batch up, inoculation, batch, fed-batch and methanol induction phases, monitoring and sampling, harvest. Acceptable ranges were defined for each variable, e.g. pH: $5 \pm 0.5$, temperature: $30 \pm 2{ }^{\circ} \mathrm{C}$, air flow: $1 \pm 0.1 \mathrm{vvm}$ flow, inoculum level: $50 \pm 5 \mathrm{~mL} / \mathrm{L}$ medium with a $\mathrm{OD}_{600}: 13 \pm 2$. In the case of the methanol feed profile, the CMO did not have the ability program an exponential methanol feed rate so this was simulated by a series of linear steps, which overlapped the exponential profile. Using a series of linear steps produced the same quality and quantity of $\operatorname{rBoNTE}\left(\mathrm{H}_{\mathrm{c}}\right)$ and was easily transferred to the CMO. The technology transfer batch records provide more process specific information as compared to our CGMP batch records which are both process specific and equipment specific. The residual methanol level was monitored by off-gas measurement using a mass spectrometer interfaced to the control software Batch-Expert via a DDE bridge as described earlier. Methanol was detected in the fermentation broth when a bolus of methanol $(1.5 \mathrm{~g} / \mathrm{L})$ was added for adaptation; the methanol level in the off-gas spikes as the cells do not utilize methanol immediately (the cells were utilizing glycerol as the carbon source), but with time the cells adapt to the methanol and this is reflected in a decrease of methanol in the off-gas (Fig. 7a). When the methanol level reduces to $(50 \pm 25 \mathrm{ppm})$, i.e. the cells utilize the initial bolus of methanol injected to the system, a second bolus of methanol $(2 \mathrm{~g} / \mathrm{L}$ broth $)$ is introduced (as a bias) and the methanol feed started, so that the control system does not oscillate to control the methanol level at $2 \mathrm{~g} / \mathrm{L}$ which is very critical for the process. The methanol level however was almost undetectable during induction, indicating that there was no accumulation of methanol in the medium (Fig. 7a). Analysis of off-gas data showed that the respiratory quotient (RQ) ranged from 0.5 to 0.7 and that the $\mathrm{CO}_{2}$ evolution rate was $2-3 \%$ during methanol induction.
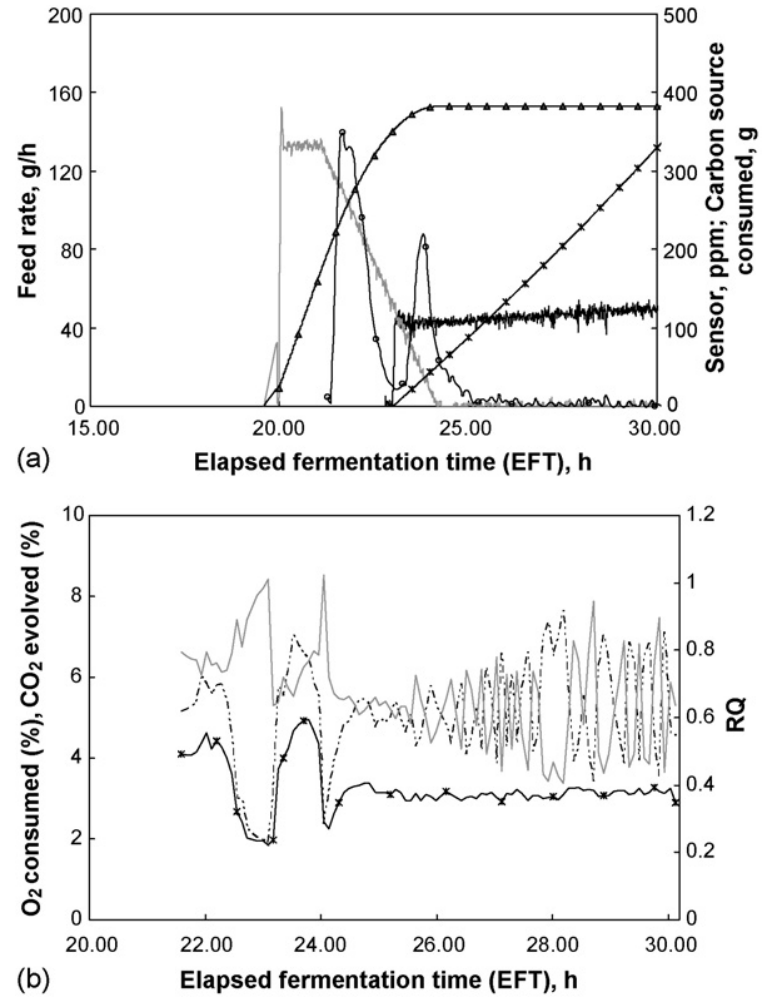

Fig. 7. Profile of various parameters and off-gas analysis during $\operatorname{rBoNTE}\left(\mathrm{H}_{\mathrm{c}}\right)$ fermentation in $19 \mathrm{~L}$ Bioengineering fermentor. (a) ) Methanol feed rate; (_ ) glycerol feed rate; (ム) amount of glycerol fed; $\left(^{*}\right)$ amount of methanol fed; $(\bigcirc)$ methanol in off-gas. (b) (_ _ _ _ ) Oxygen consumed; (*) carbon dioxide evolved; (_ $)$ respiratory quotient (RQ).

The fluctuations observed in oxygen uptake rate and RQ (Fig. 7b) were the result of a pulsating oxygen supply from the fermentor control unit which controls oxygen input by an on-off control at an oxygen requirement of less than $1 \mathrm{~L} / \mathrm{min}$. However, when the oxygen requirement is above $1 \mathrm{~L} / \mathrm{min}$, the oxygen supply was controlled at $0.1 \mathrm{~L} / \mathrm{min}$ increments resulting in smooth oxygen supply. The respiration rate increased during the transition period and then decreased gradually to a steady value throughout induction. The observed specific growth rate was $0.0237 \mathrm{~h}^{-1}$ which was close to the theoretical specific growth rate of $0.0267 \mathrm{~h}^{-1}$. The induction WCW varied between 114 and $134.2 \mathrm{~g} / \mathrm{L}$ in duplicate fermentation experiments. An induction time of $9 \mathrm{~h}$ produced $3.6 \mathrm{mg} \mathrm{rBoNTE}\left(\mathrm{H}_{\mathrm{c}}\right)$ per gram of wet cell. Cell growth, substrate utilization, and oxy- 


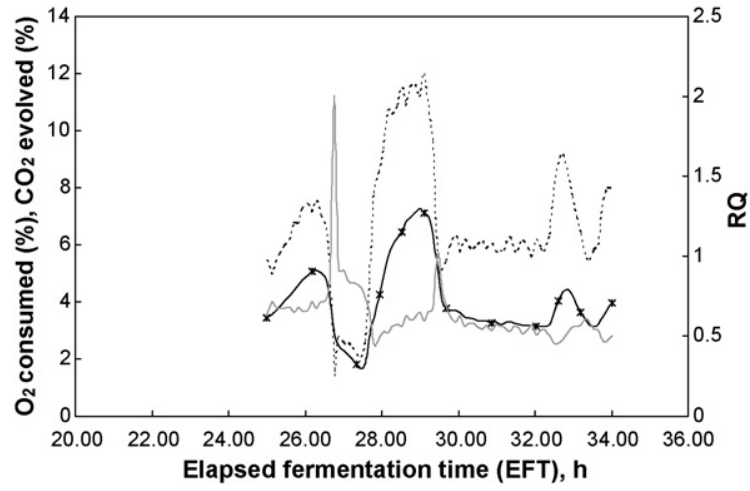

Fig. 8. Profile of off-gas analysis during $\operatorname{rBoNTE}\left(\mathrm{H}_{\mathrm{c}}\right)$ fermentation in $5 \mathrm{~L}$ Bioflo fermentor. (- - - - ) Oxygen consumed; (*) carbon dioxide evolved; (— $)$ respiratory quotient (RQ).

gen consumption rate were comparable when the process was scaled-up from the 5 to $19 \mathrm{~L}$ scale, however, $\mathrm{rBoNTE}\left(\mathrm{H}_{\mathrm{c}}\right)$ yield was $1.25 \mathrm{mg} / \mathrm{g} \mathrm{WCW}$ at $11.2 \mathrm{~h}$ in the $5 \mathrm{~L}$ bioreactor compared to $3.60 \mathrm{mg} / \mathrm{g}$ WCW produced at $9.05 \mathrm{~h}$ in the $19 \mathrm{~L}$ bioreactor. The cell density averaged an increase of 41.5 and $40 \mathrm{~g} / \mathrm{L}$ at 5 and $19 \mathrm{~L}$ scale, respectively, during the methanol fed-batch phase. The yield coefficient on methanol was $0.8 \mathrm{~g} \mathrm{WCW} / \mathrm{g} \mathrm{MeOH}$ consumed at the $5 \mathrm{~L}$ scale versus $0.71 \mathrm{~g} \mathrm{WCW} / \mathrm{g} \mathrm{MeOH}$ consumed at $19 \mathrm{~L}$ scale. The RQ varied from 0.5 to 1.0 at the $5 \mathrm{~L}$ scale which was close to the RQ values of $0.5-0.7$ at the $19 \mathrm{~L}$ scale (Figs. 8 and 9). However, the product quality was found to improve in the $19 \mathrm{~L}$ fermentor as no degradation fragments was detected by

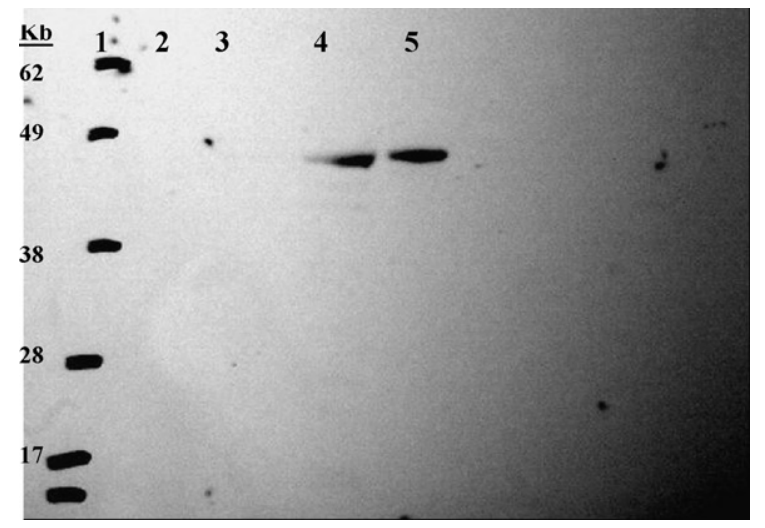

Fig. 9. Western blot time profile of $\operatorname{rBoNTE}\left(\mathrm{H}_{\mathrm{c}}\right)$ production in $19 \mathrm{~L}$ fermentor for large scale fermentation and purification. Lane 1, marker; lane 2, $0 \mathrm{~h}$; lane 3, $2.3 \mathrm{~h}$; lane 4, $9 \mathrm{~h}$; lane 5, $\operatorname{rBoNTE}\left(\mathrm{H}_{\mathrm{c}}\right)$ standard. All times refer to elapsed induction time.
Western analysis compared to $\mathrm{rBoNTE}\left(\mathrm{H}_{\mathrm{c}}\right)$ produced in the $5 \mathrm{~L}$ fermentors (Fig. 9). At this time there is no obvious or scientific reason to the significant increase in $\operatorname{rBoNTE}\left(\mathrm{H}_{\mathrm{c}}\right)$ yield at the $19 \mathrm{~L}$ scale, except that it was observed that $19 \mathrm{~L}$ system provided "smoother" control of fermentation variables and carbon source feeding.

\subsection{Studies on mouse potency bioassay of $\operatorname{rBoNTE}\left(H_{c}\right)$}

The potency of the $\mathrm{rBoNTE}\left(\mathrm{H}_{\mathrm{c}}\right)$ produced from fermentations described above was determined using a mouse bioassay. Results were subjected to probit analysis to determine the $\mathrm{ED}_{50}$, or theoretical antigen dose that will protect $50 \%$ of the mice from lethal injection. The survival of the mice after immunizations with $\mathrm{rBoNTE}\left(\mathrm{H}_{\mathrm{c}}\right)$ doses ranging from $11 \mathrm{ng}$ to $8.1 \mu \mathrm{g}$ was carried out. The calculated $\mathrm{ED}_{50}$ for this potency assay was $214 \mathrm{ng}$, with $95 \%$ confidence limits ranging from 86 to $491 \mathrm{ng}$. The $\mathrm{rBoNTE}\left(\mathrm{H}_{\mathrm{c}}\right)$ for vaccination of mice was obtained from purification of protein from the $19 \mathrm{~L}$ scale fermentation.

\section{Conclusion}

A scalable fermentation process for the manufacture of $\operatorname{rBoNTE}\left(\mathrm{H}_{\mathrm{c}}\right)$ was developed in preparation for transfer to a CGMP manufacturing facility, using a fully characterized accession cell bank. An induction time of $9 \mathrm{~h}$ was optimal for minimizing proteolytic degradation of $\operatorname{rBoNTE}\left(\mathrm{H}_{\mathrm{c}}\right)$. The process is well-defined and scale-up studies at the $19 \mathrm{~L}$ scale indicate the ability to transfer the process to pilot-scale. This process is robust and should serve as a framework for development of the remaining botulinum recombinant vaccines under development, i.e. serotypes C, F, D and G.

\section{Acknowledgements}

Research was supported by The Medical Research and Materiel Command Contract No.: DAMD17-02C-0107 and National Institute of Allergy and Infectious Disease Contract No.: 1U01 AI 056514-01. We would like to thank the BPDF's Quality Control Group and Analytical Methods Laboratory for sample analysis through out this project. Also we would like to 
thank the BPDF's Fermentation Development Laboratory staff for process development support throughout this project.

\section{References}

Blasi, J., Chapman, E.R., Link, E., Binz, T., Yamasaki, S., De Camilli, P., Sudhof, T.C., Niemann, H., Jahn, R., 1993. Botulinum neurotoxin A selectively cleaves the synaptic protein SNAP-25. Nature $365,160-163$.

Byrne, M.P., Smith, L.A., 2000. Development of vaccines for prevention of botulism. Biochimie 82, 955-966.

Byrne, M.P., Smith, T.J., Montgomery, V.A., Smith, L.A., 1998. Purification, potency, and efficacy of the botulinum neurotoxin type A binding domain from Pichia pastoris as a recombinant vaccine candidate. Infect. Immun. 66, 4817-4822.

Clare, J.J., Rayment, F.B., Ballantine, S.P., Sreekrishna, K., Romanos, M.A., 1991. High-level expression of tetanus toxin fragment $\mathrm{C}$ in Pichia pastoris strains containing multiple tandem integrations of the gene. Biotechnology 9, 455-460.

Cregg, J.M., Kimberly A.R., 1998. Transformation. In: Higgins, D.R., Cregg, J.M. (Eds.), Pichia Protocols, Methods, Mol., Biol. (Totowa, NJ), vol. 103. Humana, Totowa, NJ, 1998, pp. 27-39.

Cregg, J.M., Tschopp, J.F., Stillman, C., Siegel, R., Akong, M., Craig, W.S., Buckholz, R.G., Madden, K.R., Kellaris, P.A., 1987. Highlevel expression and efficient assembly of hepatitis B surface antigen in the methylotrophic yeast, Pichia pastoris. Bio/Technology $5,479-485$.

DasGupta, B.R., 1989. The structure of botulinum neurotoxin. In: Botulinum Neurotoxin and Tetanus Toxin. Academic Press, San Diego, CA, pp. 53-67.

DasGupta, B.R., Sugiyama, H., 1972. A common subunit structure in Clostridium botulinum type A, B and E toxins. Biochem. Biophys. Res. Commun. 48, 108-112.

Dreyer, F., Habermann, E., 1986. Clostridial neurotoxins, handling and action at the cellular and molecular level. Current Topics in Microbiology and Immunology 129, 93-179.

Foran, P., Lawrence, G.W., Shone, C.C., Foster, K.A., Dolly, J.O., 1996. Botulinum neurotoxin $\mathrm{C} 1$ cleaves both syntaxin and SNAP-25 in intact and permeabilized chromaffin cells, correlation with its blockade of catecholamine release. Biochemistry $35,2630-2636$.

Gellissen, G., 2000. Heterologous protein production in methylotrophic yeasts. Appl. Microbiol. Biotechnol. 54, 741-750.

Hatheway, C.L., 1989. Bacterial sources of Clostridial neurotoxins. In: Botulinum Neurotoxin and Tetanus Toxin. Academic Press, pp. 4-26.
Inan, M., Meagher, M.M., 2001. Non-repressing carbon sources for alcohol oxidase (AOX1) promoter of Pichia pastoris. J. Biosci. Bioeng. 92, 585-589.

Jahn, R., Südhof, T.C., 1999. Membrane fusion and exocytosis. Ann. Rev. Biochem. 68, 863-911.

Jones, L.J., Upson, R.H., Haugland, R.P., Panchuk-Voloshina, N., Zhou, M., Haugland, R.P., 1997. Quenched BODIPY dye-labeled casein substrates for the assay of protease activity by direct fluorescence measurement. Anal. Biochem. 251, 144-152.

Loveless, B.M. 2001. Clostridium botulinum neurotoxin type E binding domain from Pichia pastoris as a recombinant vaccine candidate. Master of Science Thesis. Hood College, Frederick, MD.

Medical and Public Health Management, 2001. Botulinum toxin as a biological weapon. JAMA 285, 1059-1070.

Niemann, H., Blasi, J., Jahn, R., 1994. Clostridial neurotoxins, new tools for dissecting exocytosis. Trends Cell. Biol. 4, 179-185.

Pellizzari, R., Rossetto, O., Schiavo, G., Montecucco, C., 1999. Tetanus and botulinum neurotoxins, mechanism of action and therapeutics. Philos. Trans. R. Soc. London. Ser. B 354, 259-268.

Schiavo, G., Santucci, A., Dasgupta, B.R., Mehta, P.P., Jontes, J., Benfenati, F., Wilson, M.C., Montecucco, C., 1993. Botulinum neurotoxins serotypes A and E cleave SNAP-25 at distinct COOH-terminal peptide bonds. FEBS Lett. 335, 99-103.

Simpson, L.L., 1986. Molecular pharmacology of botulinum toxin and tetanus toxin. Ann. Rev. Pharmacol. Toxicol. 26, 427-453.

Sinha, J., Inan, M., Meagher, M.M., 2005. Causes of proteolytic degradation of secreted recombinant proteins produced in methylotrophic yeast Pichia pastoris—case study with recombinant ovine interferon- $\tau$. Biotechnol. Bioeng. 89, 102-112.

Sinha, J., Plantz, B.A., Zhang, W., Gouthro, M., Schlegel, V., Liu, C.P., Meagher, M.M., 2003. Improved production of recombinant ovine interferon- $\tau$ by mut $^{+}$strain of Pichia pastoris using an optimized methanol feed profile. Biotechnol. Prog. 19, 794-802.

Smith, L.A., 1998. Development of recombinant vaccines for botulinum neurotoxin. Toxicon 36, 1539-1548.

Smith, L.A., Jensen, M.J., Montgomery, V.A., Brown, D.R., Ahmed, S.A., Smith, T.J., 2004. Roads from vaccines to therapies. Mov. Disord. 19, S48-S52.

Southern, E.M., 1975. Detection of specific sequences among DNA fragments separated by gel electrophoresis. J. Mol. Biol. 98, 503-517.

Sreekrishna, K., Kropp, K.E., 1996. Pichia pastoris. In: Wolf, K. (Ed.), Non-conventional Yeasts in Biotechnology. Springer, Berlin, pp. 277-291.

Zhang, W., Bevins, M.A., Plantz, B.A., Smith, L.A., Meagher, M.M., 2000. Modeling Pichia pastoris growth on methanol and optimizing the production of a recombinant protein, the heavy-chain fragment $\mathrm{C}$ of botulinum neurotoxin, serotype A. Biotechnol. Bioeng. 70, 1-8. 